\title{
Lessons from Refugees
}

\section{Research Ethics in the Context of Resettlement in South America}

\author{
Marcia Vera Espinoza
}

ABSTRACT: Refugees are the main experts on their own experiences of displacement. They constantly challenge academic research practice and ethical guidelines, as their own lives are under study. This article shares some reflections from research with Colombian and Palestinian resettled refugees in Chile and Brazil, shedding light on refugees' agency in determining what constitutes safe and ethical research practices.

KEYWORDS: gatekeepers, positionality, research ethics, refugees, refugee resettlement, South America

From 2012 to 2015 I conducted research exploring the experiences of resettlement of a group of Colombian and Palestinian refugees in Chile and Brazil (Vera Espinoza 2015, 2017, 2018a, 2018b). The research methodology used a qualitatively driven mixed-methods approach (Mason 2006) that included semistructured interviews, a survey, and participant observation in two countries. While both populations of concern were well-defined within the study, these resettled refugees were distributed in different cities and municipalities within Chile and Brazil. Access to participants, in this context, was one of the main challenges I faced when I started the project. Access also became a point of critical reflection, as refugees themselves raised a number of issues that were beyond the ethical considerations applied as part of standard academic guidelines. ${ }^{1}$

The research project opted for a complex matrix of diverse sites and research participants that included two countries, fifteen cities, and refugees from two distinct communities, in order to explore how refugees coming from inside and outside the region experienced resettlement and how the program of resettlement has been implemented in South America (showing the strengths and weaknesses in existing initiatives). In order to achieve this aim, the research included 80 semistructured interviews with refugees and other stakeholders involved in the program (government officials, NGO staff, UNHCR staff, and translators, among others). Despite the strengths of the approach, which included multiple voices and spaces, the research process was still problematic. Besides the questions of "Who speaks for whom?" (Kobayashi 1994), and who can speak and upon which interests (Spivak 1988), the study took place within material and discursive spaces embedded within power imbalances, where I found myself reproducing and/ or reacting to some of these practices. Three main issues emerged from these reflexive discussions with refugees: access and the use of gatekeepers, the negotiation of power imbalances, and research fatigue. The discussion of these three themes provides relevant reflections about ethics within academic research as well as refugees' agency in determining what constitutes safe and ethical practices for themselves. 


\section{The Ethical Challenges of Access through Gatekeepers}

Access to participants was challenging and fascinating at the same time, as the negotiation of that access shed light onto the relationships and tensions between the actors involved in refugee resettlement in both Chile and Brazil (Vera Espinoza 2018b). I used different strategies to reach participants, mainly through gatekeepers and snowballing. In both research sites I conducted participant observation in the offices of two NGO implementing partners of the United Nations High Commissioner for Refugees (UNHCR). On the one hand, doing participant observation in these places allowed me to gain firsthand insight into the context, relationships, and information produced in both NGOs. On the other hand, the use of participant observation was intended as a strategic platform from which to understand the different scales and actors involved in resettlement, and also as a channel through which to gain access to those people and institutions, including refugee participants.

The use of gatekeepers as a means of accessing interviewees was rather problematic, since it assumed that NGOs would provide access on behalf of other participants, such as other organizations and refugees, who may not know about the research otherwise (O'Reilly 2009). However, this has been a common approach in refugee studies, since it has been recognized that some organizations control "access to refugees," demonstrating the power relationships within the refugee system. Barbara Harrell-Bond and Eftihia Voutira (2007: 284) argued that an "underlying fear of bad publicity" is one of the main reasons why the UNHCR and NGOs are ambivalent in allowing research within refugee communities, imposing control through different bureaucratic structures. In the context of Chile and Brazil, accessing refugees through the NGOs was an effective use of gatekeepers, but sometimes a challenging one.

I was reflexive about the reproduction of power dynamics by approaching the organizations first. However, the organizations provided the contacts, and my approach to participants was always direct, as NGOs on the ground did not have the time or the intention to contact participants on my behalf. I also took extra care in informing refugees that, despite getting their contact through the organizations, I did not have an institutional commitment with them. Considering the tense relationship that some refugees had with the implementing organizations (Moulin 2012; Vera Espinoza 2018b), it would have been challenging if participants associated me with the NGO team (see Kawulich 2005). At the same time, during the negotiation of my presence in both NGOs, I made clear my stance as researcher, emphasizing that I would not share information about the refugees with the organizations.

\section{Security Concerns}

Beyond the considerations taken as part of this approach, getting access through the NGOs also raised some security concerns, as one of the families I interviewed emphasized in our first encounter. In April 2013 I interviewed a Colombian family in Chile. Once I contacted them over the phone and they agreed to the interview, they asked me to meet in the food court of a busy shopping center in Santiago. When I asked them why they chose that place, they told me that it was related to their own safety. I described this exchange in my field journal:

They didn't feel safe anymore in the resettlement country due to the increase of the Colombian population and they thought that the NGO was not prepared to handle their safety concerns. In this sense, Luis ${ }^{2}$ told me: "I don't have any problem with you now that I know you, but don't you think it is a questionable practice that the organization gave you our contact 
details without letting us know first? What if the person that asks doesn't have good intentions?" And then it hit me, he was totally right. The NGO is a gatekeeper with such control over them that it doesn't really consider the refugees' decision over their own information. What about me? Am I helping to reproduce these dynamics of power? (April 2013)

In this case, the refugees themselves adopted the security measures they considered necessary, such as to meet me in public and to learn more about me before they decided if they wanted to take part in the study.

In both countries, the NGOs were the main gatekeepers to refugees. During fieldwork I found myself questioning the criteria upon which institutions control refugees' contact details and how they decided what information they provided or not. I felt that the criteria were based on portraying successful stories instead of refugees' security. As Gill Valentine (2005) has stated, the use of gatekeepers carries the risk that they will try to impose their own agenda by directing the researcher to a specific selection of participants. In the case of this research, NGOs initially tended to provide the contact information for refugees regarded as success stories, the same contacts that they provided to the UNHCR and the press to write their stories. At some point, and after my persistent requests to access a wider group of refugees, both institutions in both countries offered me access to refugees' files in order to get their contact information. I perceived that by doing that, both NGOs were trying to show transparency about their work. However, I found it problematic that the consent to explore those files-which included extensive and detailed information about people's displacement and personal history-was given without the consent of the refugees themselves. This was an ethical issue, and I decided not to use or review refugees' files. However, I did use the unsorted Excel sheet with people's contact details, knowing that this also represented an intrusive practice. My reasoning, however, was that by contacting the refugees directly, they would be the ones to decide if they wanted to share their experiences or not.

The other strategy implemented to access participants was through snowballing (Bryman 2012). This technique of engagement through another contact (in this case, another refugee) proved to be effective in providing refugees with more confidence in their decision to participate in the study.

\section{Positionality and Power Imbalances}

After I explained the research and the participants agreed to meet me, a second negotiation took place. I was a total stranger knocking at people's doors. Considering refugees' traumatic experiences before and during displacement, their encounter with strangers is already difficult, and I had to ensure extra care in making them feel safe. In this context, and against my initial expectations, the information sheet and consent form requested by the institutional ethics committee played a pivotal role. The information sheet, translated into Spanish and Arabic, gave participants a sense of security. At the same time, the formality of the consent form also gave participants a sense of control and a guarantee of anonymity (Mason 2002; Valentine 2002). All participants were given time to read the information (or have it explained orally if they were illiterate or had a visual impediment) and ask questions of me. They also signed a consent form (or gave oral consent on a recorder if they were unable or unwilling to sign) where they agreed to be part of the research.

Usually each visit would take between two and four hours. After they exhausted all their questions about the research project, a more personal encounter took place, an encounter that 
was necessary for the establishment of trust between myself and the refugees, and crucial to the success of the research. As Tricia Hynes (2003) asserts, refugees are the experts on their own experience, and access to that expertise depends to a great extent on how the researcher handles issues of mistrust. Many of these encounters took place while sharing food. Food became an instrument to recognize our differences and sameness, allowing us to share stories and experiences at a "neutral table." At the same time, sharing "their" food enabled a shift in the power relations embedded in the interview. Through their cooking, refugees evoked and shared their memories of home (Law 2001) while at the same time taking ownership of our encounter. I did not ask them to cook and it was not considered part of my methodology. When it happened, the cooking was their proposal of intervention within the interview process. I registered this in my field journal:

Access. This word has been persistent in my mind and in my notes since the fieldwork in Chile. Access at different levels. Access as negotiation and sharing. Material access ... For example, when some participants decided to open the doors of their houses and the door to their stories, this usually came with food. And it makes sense. Not that they thought I needed it, but because opening the details of their experiences for sure needs to come with something else, like food, a sort of instrument that takes out the tension, that gives us proximity and puts us at the same table despite all our differences. Food opened a space to share the memories. (January 2014)

In this negotiation of access, my own multiple selves became relevant. Participants wanted to know about me as much as about the research. Usually their questions addressed my identity as an immigrant, as a woman, or as a Latin American scholar. By sharing my experience living abroad as a minority and my experiences with a different language and culture, I was not losing my "objectivity" as a researcher. Instead, the participants and I were engaging in a mutual recognition of our subjective beings (O'Connell Davidson and Layder 1994). Despite our common membership in the global community of border crossers, the privilege of my migration by choice and not by persecution-among many other privileges-also reinforced our differences. This left us in an in-between space that challenged the dichotomy of insider versus outsider status, as suggested by Sonia Dwyer and Jennifer Buckle (2009, see also Carling et al. 2014). Each of the refugees and I have multiple selves and identities, unfolded and reproduced during the interview process (Valentine 2002), which provided common ground or reinforced our differences.

This recognition also highlighted the dilemma of how my own multiple identities played out across different scales of the research process, framed within a refugee system marked by power and privilege. While I was creating rapport with refugee participants and obtaining valuable access, I was also "othering" them in the same research process, by accessing them through the NGOs or by assessing the program through their experiences (see Villenas 1996). This took me through a process of rethinking my research questions and focus, from an initial top-down approach that privileged the role of the state and governance structures in order to understand resettlement, to one that emphasized refugees' experiences and the negotiations they developed within and across these governance structures. Overall, I believe that the reflexivity that emerged from my encounters with the participants allowed us to explore tensions and recognize our multiple identities, producing rich conversations in a situated context based on mutual respect. At the end, as Nando Sigona (2014: 378) asserts, the interview process is a "performance in which the meanings of questions and responses are contextually grounded and jointly constructed." However, as reflexive as my encounters were, I cannot claim to have produced nonproblematic research. Power relations were embedded in those encounters from the moment I obtained their numbers and called them without them being aware. 


\section{Research Fatigue}

Another challenge that emerged at an early stage of the research was the research fatigue among the Palestinian communities (see also Clark 2008; Karooma 2019). The Palestinian resettlement program in Chile and Brazil was considered a novel approach to South-South refugee protection in South America, and as such it received relevant financial support from international donors such as Norway, the United States, and Canada, as well as great interest from the international community and visibility in the local and the international media (Vera Espinoza 2018a). This meant that some Palestinian refugees, particularly the ones that spoke better Spanish/Portuguese or the first ones who had obtained jobs, were interviewed repeatedly by the local and international press, by the UNHCR, and by local researchers (see also Omata 2019).

Refugees who did not want to participate in the research were extremely polite but firm in their decision. During the fieldwork in Chile I met a Palestinian refugee who I had interviewed as part of a newspaper article back in 2010. I realized that it was her when I went to her house to interview her son. When I asked if she also wanted to be part of the study, she said no. She added: "To be honest, I am just tired of talking about my life. I just want to live. I don't want to remember anymore." Like her, at least four Palestinians in Chile and another three in Brazil declined my invitation to be part of the study, citing their "tiredness" from being questioned by researchers. In addition, they did not see any long-term benefit or feedback from the projects in which they had previously participated. This "research fatigue" among Palestinian refugees provided useful insights about how the resettlement programs managed access to refugees in both countries, as this feeling of being “overresearched" resulted from the NGOs' and UNHCR's practices of portraying successful stories, meaning that specific refugees were frequently identified as the "preferred" interviewees. Research fatigue also emphasized the extractive nature of research, revealed in participants' complaints about lack of retribution or benefits as well as claims about a lack of follow-up on the part of researchers (Karooma 2019).

Contrary to the experience of some Palestinian refugees, most Colombian refugees were eager to talk about their experiences, as they believed there was little attention to their resettlement. The different approach to this community sheds light on some of the politics of refugee protection, as Colombian refugees in both countries received less or no interest from the local and international media and academia, as well as considerably less funding from the international community (Vera Espinoza 2018a). The "underresearched" experience of Colombian refugees in the context of resettlement was met with complaints of exclusion from academic and policy debates (Omata 2019).

\section{Moving Forward}

The importance of researchers' reflexivity and research ethics has been one of the main contributions of feminists and other critical geographers (Kobayashi 1994; England 1994; Valentine 2002), and it is an increasing concern among academics and practitioners alike (see Clark-Kazak 2017; Forced Migration Review 2019; IASFM 2018; Krause 2017; Refugee Studies Centre 2007). As academics continue working in interdisciplinary settings with multiple stakeholders, we need to recognize that each of us has specific interests as well as diverse understandings of what the research is for and what its ethics are (Vera Espinoza and Connelly 2018), as well as to think about how our various identities shape "research encounters, processes and outcomes" (Hopkins 2007: 387).

This demands clear communication with stakeholders, recognizing the levels of power and vulnerability involved in refugee research. At the core of these concerns, a priority must be to 
include asylum seekers and refugees themselves in the discussion. Refugees are the main experts about their experiences, and as shown here, they can and do challenge our academic research practices as they determine what are the safe and ethical practices we should engage with when researching their experiences.

\section{ACKNOWLEDGMENTS}

I would like to thank the anonymous referee for their thoughtful comments. This research would not have been possible without the experiences and insights shared by refugees, nor without the funding I received from CONICYT and fieldwork grants from RGS-IBG Slawson Award, SLAS, and SIID.

MARCIA VERA ESPINOZA is a Lecturer in Human Geography at Queen Mary University of London, UK. Her research focuses on refugee and migrant inclusion, migration governance, and immigration policies in Latin America. Her work has recently been published in Geopolitics, Global Policy, Forced Migration Review, and Development Policy Review. Her coedited book The Dynamics of Regional Migration Governance was published by Edward Elgar in June 2019. ORCID: https://orcid.org/0000-0001-6238-7683.

\section{NOTES}

1. This project received ethical approval in July 2012. Participants were assured anonymity and were made aware that they could withdraw from the study at any point.

2. All participants' names have been replaced with pseudonyms.

\section{REFERENCES}

Bryman, Alan. 2012. Social Research Methods. 4th ed. Oxford: Oxford University Press.

Carling, Jørgen, Marta Bivand Erdal, and Rojan Tordhol Ezzati. 2014. "Beyond the Insider-Outsider Divide in Migration Research." Migration Studies 2 (1): 36-54.

Clark, Tom. 2008. “'We're Over-Researched Here!': Exploring Accounts of Research Fatigue within Qualitative Research Engagements." Sociology 42 (5): 953-970.

Clark-Kazak, Christina. 2017. "Ethical Considerations: Research with People in Situations of Forced Migration." Refuge 33 (2): 11-17.

Dwyer, Sonia Corbin, and Jennifer L. Buckle. 2009. “The Space Between: On Being an Insider-Outsider in Qualitative Research.” International Journal of Qualitative Methods 8 (1): 54-63.

England, Kim. 1994. “Getting Personal: Reflexivity, Positionality, and Feminist Research.” The Professional Geographer 46 (1): 80-89.

Forced Migration Review. 2019. "The Ethics Issue: Exploring Ethical Questions that Confront us in our Work." Issue 61 (June).

Harrell-Bond, Barbara, and Eftihia Voutira. 2007. "In Search of 'Invisible' Actors: Barriers to Access in Refugee Research.” Journal of Refugee Studies 20 (2): 281-298.

Hopkins, Peter. 2007. "Positionalities and Knowledge: Negotiating Ethics in Practice." ACME: An International E-Journal for Critical Geographies 6 (3): 386-394.

Hynes, Tricia. 2003. “The Issue of 'Trust' or 'Mistrust' in Research with Refugees: Choices, Caveats and Considerations for Researchers." New Issues in Refugee Research, Working Paper Number 98. 
IASFM. 2018. “Code of Ethics." Retrieved 27 September 2019 from http://iasfm.org/blog/2018/11/30/ adoption-of-iasfm-research-code-of-ethics.

Kawulich, Barbara B. 2005. "Participant Observation as a Data Collection Method." Forum: Qualitative Social Research 6 (20), [81 paragraphs]. Retrieved 28 August 2019 from http://nbn-resolving.de/ urn:nbn:de:0114-fqs0502430.

Karooma, Cleophas. 2019. "Research Fatigue among Rwandan Refugees in Uganda." Forced Migration Review 61: 18-19.

Kobayashi, Audrey. 1994. “Coloring the Field: Gender, 'Race,' and the Politics of Fieldwork." Professional Geographer 46 (1): 73-80.

Krause, Ulrike. 2017. "Researching Forced Migration: Critical Reflections on Research Ethics during Fieldwork." Refugee Studies Centre, Working Paper Number 123.

Law, Lisa. 2001. "Home Cooking: Filipino Women and Geographies of the Senses in Hong Kong." Ecumene 8 (3): 264-283.

Mason, Jennifer. 2002. Qualitative Researching. 2nd ed. London: SAGE Publications.

Mason, Jennifer. 2006. "Mixing Methods in a Qualitatively Driven Way." Qualitative Research 6 (1): 9-25.

Moulin, Carolina. 2012. "Ungrateful Subjects? Refugee Protest and the Logic of Gratitude." In Citizenship, Migrant Activism and the Politics of Movement, ed. Peter Nyers and Kim Rygiel, 54-72. Abingdon, UK: Routledge.

O'Connell Davidson, Julia, and Derek Layder. 1994. Methods, Sex and Madness. London: Routledge.

Omata, Naohiko. 2019. “'Over-researched' and 'Under-researched' Refugees." Forced Migration Review 61: 15-18.

O’Reilly, Karen. 2009. “Key Informants and Gatekeepers.” In Key Concepts in Ethnography, 132-138. London: SAGE Publications.

Refugee Studies Centre. 2007. "Ethical Guidelines for Good Research Practice." Refugee Survey Quarterly 26 (3): 162-172.

Sigona, Nando. 2014. “The Politics of Refugee Voices: Representations, Narratives, and Memories." In The Oxford Handbook on Refugee and Forced Migration Studies, ed. Elena Fiddian-Qasmiyeh, Gil Loescher, Katy Long, and Nando Sigona, 367-382. Oxford: Oxford University Press.

Spivak, Gayatri Chakravorty. 1988. "Can the Subaltern Speak?” In Marxism and the Interpretation of Culture, ed. Cary Nelson and Lawrence Grossberg, 271-313. Basingstoke, UK: Macmillan.

Valentine, Gill. 2002. "People Like Us: Negotiating Sameness and Difference in the Research Process." In Feminist Geography in Practice: Research and Methods, ed. Pamela Moss, 116-126. Oxford: Blackwell.

Valentine, Gill. 2005. "Tell Me About ... Using Interviews as a Research Methodology." In Methods in Human Geography: A Guide for Students Doing a Research Project, ed. Robin Flowerdew and David Martin, 110-127. Harlow: Pearson Education Limited.

Vera Espinoza, Marcia. 2015. "Experiences of 'Unsettlement': Exploring the 'Integration' of Palestinian and Colombian Refugees Resettled in Chile and Brazil." PhD diss., University of Sheffield.

Vera Espinoza, Marcia. 2017. "Extra-regional Refugee Resettlement in South America: The Palestinian Experience." Forced Migration Review 56: 47-49.

Vera Espinoza, Marcia. 2018a. "The Limits and Opportunities of Regional Solidarity: Exploring Refugee Resettlement in Brazil and Chile." Global Policy 9 (1): 85-94.

Vera Espinoza, Marcia. 2018b. “The Politics of Resettlement: Expectations and Unfulfilled Promises in Chile and Brazil." In Refugee Resettlement: Power, Politics and Humanitarian Governance, ed. Adèle Garnier, Liliana Lyra Jubilut, and Kristin Bergtora Sandvik, 223-243. New York: Berghahn Books.

Vera Espinoza, Marcia, and Steve Connelly. 2018. "Understanding Ethics of Doing Interdisciplinary Research with Refugee Communities (or Trying To!)." SIID Blog, Sheffield Institute for International Development, 1 August 2018. Retrieved 27 August 2019 from http://siid.group.shef.ac.uk/blog/ understanding-ethics-of-doing-interdisciplinary-research-with-refugee-communities-or-trying-to/.

Villenas, Sofia. 1996. "The Colonizer/Colonized Chicana Ethnographer: Identity, Marginalization, and Co-optation in the Field." Harvard Educational Review 66 (4): 711-731. 